Journal of Strategic Marketing, Volume 14, Number 2, June 2006, pp. 101-113

Profitable relationships with key customers: how suppliers manage pricing and customer risk

Lynette Ryals, MA (Oxon), MBA, PhD, FSIP

Professor of Strategic Sales and Account Management

Centre for Advanced Research in Marketing

Cranfield School of Management

Cranfield University

Cranfield

Bedford MK43 0AL

Tel: 01234751122

Fax: 01234752691

email: lynette.ryals@cranfield.ac.uk

Accepted without revision by: Journal of Strategic Marketing 


\section{Profitable relationships with key customers: how suppliers manage pricing and customer risk}

Increasingly, the measurement and management of customer profitability and customer lifetime value are recognized as important elements in marketing's contribution to shareholder value. In recent years numerous papers have been written about the value of customers, mostly case study based and confined to analysis of single companies or industries. This paper reports on research that takes a wider perspective and examines how best-practice companies across a range of different industries try to manage their relationships with key customers profitably. The contribution of this research is to show how best-practice companies manage pricing, costs to serve, and customer risk in their key account portfolios.

KEYWORDS: Customer lifetime value; customer portfolio; key account management; pricing; customer risk

\section{INTRODUCTION}

In a business environment in which marketing is being challenged to demonstrate its contribution to shareholder value (Doyle, 2000), the issue of whether customers are profitable and how to measure their profitability is becoming increasingly important (Reinartz and Kumar, 2000, 2002). Studies have indicated that some proportion of customers is unprofitable, at least in the short term (for example, Wilson, 1996; van Raaij, Vernooij and 
van Triest, 2003), although the degree to which customers are profitable or unprofitable can change substantially from period to period (Wilson, 1996).

Because of these period-to-period fluctuations in customer profitability it is not a suitable measure to support decisions regarding the longer term. Relationship marketing decisions are taken with regard to the entire relationship with the customer and typically take into account the longer term. A more suitable measure than customer profitability is needed and recent academic attention has shifted towards customer lifetime value and customer equity (Berger and Nasr, 1998; Mulhern, 1999; Blattberg, Getz, and Thomas, 2001; Rust, Lemon, and Ziethaml, 2001; Hogan, Lemon and Rust, 2002) as the measures of the value of the customer that are appropriate to a relationship marketing context.

Customer lifetime value is the forecast value of an individual customer throughout the lifetime of their relationship with the company (Berger and Nasr, 1998; Mulhern, 1999). It is therefore of considerable interest to key account managers, whose individual customers are so large that their lifetime value can and should be studied individually. Indeed, many key account managers are now tasked to manage not just the revenues but also the stream of profits from these substantial customers (Woodburn and McDonald, 2001).

Customer equity is the potential value of the entire customer base, calculated as the sum of customer lifetime values within the customer portfolio (Blattberg, Getz and Thomas, 2001). This measure is important to senior marketers managing marketing portfolios. There are indications that customer equity provides a better guide to the overall value of a company than other, more traditional ways of valuing businesses (Gupta and Lehmann, 2003).

Case studies analyzing customer profitability, customer lifetime value and customer equity are becoming more numerous, as are normative discussions about how the value of customers should be measured, some relatively technical (for example, Berger and Nasr, 1998; Mulhern, 
1999; Blattberg, Getz and Thomas, 2001; Ryals, 2003b). Where previous research has analyzed customer profitability and customer lifetime value it has often been on a case study basis within a single company and industry (for example, Kalwani and Narayandas, 1995; van Raaij, Vernooij and van Triest, 2003). No previous studies have surveyed different companies across different industries to review empirical approaches to the management of customer profitability or lifetime value. The current research fills this gap by reporting on a study of ten best-practice global companies in eight different industries, ranging from banking to pharmaceuticals, from food and beverage to energy and high technology. In a series of interviews with each company, all of whom measured key customer profitability and lifetime value, researchers explored their approach to managing the profitability of these key relationships. The results showed that pricing, costs to serve, portfolio management and customer risk management were critical elements in managing the value of the customer from the suppliers' point of view.

The research reveals that best-practice companies adopt a variety of approaches to pricing that reflect the relationship with their key customers. They also manage the costs to serve such customers, although they are frequently under pressure from their key accounts to increase service levels. Finally, best-practice companies are aware of the importance of their key customer portfolio as a whole. They adopt certain portfolio management strategies, which include awareness and management of customer risk.

\section{MEASURING AND MANAGING THE VALUE OF CUSTOMERS}

Customer profitability is calculated on a single period basis, usually the last full year of the customer's relationship with the business. The revenues and costs to serve associated with a customer (or with a tranche of customers, as described in Wilson, 1996) are identified (Mulhern 1999). There are problems for some companies in achieving even this snapshot 
view of the customer; many companies have management accounting systems that run along product, rather than customer, lines, so identifying the revenues and costs associated with a customer's purchases across an entire product range can be problematic (Hill and Harland, 1983).

Where customer revenues have to be estimated (or forecast, as in the calculation of customer lifetime value or customer equity), the RFM (Recency, Frequency, Monetary amount) approach is sometimes used. This approach, which has been recently criticized (Reinartz and Kumar, 2003), uses the analysis of historic purchasing patterns to determine historic and sometimes future value. Forecasting tools and data processes may be brought into play (Ryals, 2003a). Where key customers are concerned, the amounts involved and their importance to the company usually call for more precise forecasting. In such cases, customer revenues are determined from the mix of products that customers buy and the prices that they pay. Because products and services to key customers are more likely to be heavily customized, prices may be set customer by customer. The literature suggests that it is in this situation that value-based pricing may be used.

\section{Value-based pricing}

As one of the marketing's traditional 4 Ps, pricing is a core element of the marketing mix. Marketers argue for value-based pricing, where the price of the product is set with regard to the value to the customer. In practice, the majority of companies price their products or services with respect to the cost of production, adding a margin (cost-plus), or they price relative to the competition (Urbany, 2001; Hunt, 2002; Ryals, 2002b). One study of ten different pricing strategies found that cost-plus pricing was used by $56 \%$ of respondents (Noble and Gruca, 1999), more than any other pricing strategy. 
Value-based pricing, also known as value-in-use pricing, sets prices depending on how much the products or services are worth to customers (Stedman, 2000). Here, price is a 'sacrifice' and the expected value to the customer is the positive value-creation of product and service attributes on the one hand, less the value-reducing aspects of price and risk (Naumann, 1995). When goods and services are sold, value is created for customers and, in exchange, they create value for companies by paying for those products or services (McTaggart, Kontes and Mankins, 1994). The level at which value-based prices are set reflects the exchange of value rather than the costs of production.

The fact that most companies use pricing strategies that do not reflect the value exchange and therefore fail to connect value and price (A.T. Kearney, 2003) means that, at least in principle, companies may be under pricing their goods and services, possibly considerably (Hunt, 2002). For those companies who are both providing excellent value to customers and who are prepared to try to measure that value, the profit potential of an effective value-based pricing strategy is far greater than with any other pricing strategy (Monroe, 2004).

\section{Costs to serve}

Any difficulties in determining customer revenues pale, however, when compared with the problems of costs. The literature tends to suggest that customer costs are usually divided into two; there are the direct costs associated with the products that the customer buys, and the indirect costs of serving the customer (for example, Shapiro et al.,, 1987; Bolen and Davis 1997). Of the two, it is the indirect costs, the costs to serve, that are the most intractable. Many companies find difficulty in allocating these to customers. These are the costs that are listed in the P \& L account as SGA costs - sales and general administration. They can include sales, marketing, customer service, admin, and sometimes logistics (Niraj, Gupta and Narasimhan, 2001). 
One solution is to allocate these costs proportional to the revenues that the customer generates or to the volumes purchased. The problem here is that customers vary in the service demands they place on companies. Allocating SGA costs proportional to revenues or volumes will overstate the profitability of customers who are more demanding and understate the profitability of customers who are easier to deal with (Ryals, 2003b). Allocating costs to serve proportional to revenues or volumes tells a company very little more than the revenue or cost data. Certainly, it reveals nothing about the relative costs to serve and relative profitability of different customers and different purchasing behavior. This is not a problem where the SGA costs are small, or where the differences in customer buying behavior or slight. However, a survey of the Fortune 500 companies in the US revealed that SGA costs were the second largest cost item after product costs and were growing up to four times as fast (Howell and Soucy, 1990). In other words, not only is the problem of SGA allocation a large one, it is a growing issue.

\section{Activity-based costing}

A partial answer to the problem of SGA cost allocation is the use of standard costs. Standard costs are a calculated cost of a particular activity, such as raising an invoice for a customer. The standard cost of raising the invoice is then multiplied by the number of invoices raised to that client during the year; this gives the approximate cost of invoicing that client.

However, many companies wanting to calculate customer profitability or customer lifetime value want to do so in respect of their key accounts (this is discussed below). For key accounts, it is not the small items such as the numbers of invoices or credit notes that have the real impact on profitability. Instead, it is the cost of key account management that is the major cost to serve. 
A measurement tool that enables companies to recognize the differing costs to serve of its customers is activity-based costing ( $\mathrm{ABC}$ ). Originally developed by the accountancy profession as a method for allocating product costs, $\mathrm{ABC}$ has been adopted by companies wanting to calculate the value of their customers. When applied to the calculation of customer profitability (Cooper and Kaplan, 1991; Hope and Hope, 1997) the results were startling; in the case reported by Cooper and Kaplan, the US company Kanthal found that $20 \%$ of its customers brought it $220 \%$ of its profits. $70 \%$ broke even, and $10 \%$ accounted for minus $120 \%$ of profits. Cooper and Kaplan made the observation that some of Kanthal's largest customers were amongst the most unprofitable. This observation indicates the importance of customer portfolio management and the possible exposure of companies like Kanthal to certain risks in their customer relationships.

\section{Marketing portfolios and the risk of the customer}

The notion of portfolio management is not new in marketing and academics have discussed the product portfolio (for example, Bordley 2003) and the brand portfolio (for example, Petromilli, Morrison, and Million 2002). The purpose of treating a set of products or brands as a marketing portfolio is to promote a debate about how the profits of the portfolio as a whole can be maximized and to determine the most efficient allocation of marketing spend (Larréché and Srinivasan 1981, 1982).

Recently, several researchers have suggested that the customers of an organization can also be viewed as a portfolio (Rust, Lemon, and Zeithaml, 2001; Ryals, 2002a; Dhar and Glazer, 2003; Johnson and Selnes, 2004). Here, the objective is the maximization of customer equity (Lemon, Rust and Zeithaml, 2001). 
The theory of portfolio management derives from the financial field and the management of portfolios of stocks and shares (for example, Brealey, 1983). In the financial field, portfolio theorists point out that the objective of investors is not profit maximization, since profit maximization might entail unacceptable levels of risk. In fact, modern portfolio theory holds that the aim of the investor is to maximize return and minimize risk (Sharpe 1981; Brealey 1983) and there is empirical evidence that investors do in fact behave in this way (Ferguson 1987). Applying portfolio theory to marketing requires some consideration of the risk of the customer, and there has been some recent research into how this might be done (Ryals 2002a and 2003b; Dhar and Glazer, 2003).

\section{METHODOLOGY}

Because the aim of the research was to examine best practice in the profitable management of key customer relationships, an expert sampling technique using the advice of a senior academic in the KAM field was used to draw up a list of companies considered to represent best practice. All were blue-chip global firms with their headquarters in the US or in Europe. The sample frame used for this list was membership of SAMA (the Strategic Account Management Association) in the US or of the Cranfield Best Practice KAM Club in the UK.

The quality of the sample was confirmed through academic and practitioner validation and through review of the results. The findings from one company have been excluded from the results as it was deemed not to represent best practice. The final sample size was 10 companies. 
To ensure robust and generic results, a spread of companies across different sectors was sought. Companies from the financial services, energy, technology, pharmaceuticals, food and beverage, credit services, logistics, and travel sectors were selected.

Based on the literature, a discussion outline was prepared covering some 15 topics related to profitable customer management. The internal validity of the discussion outline was confirmed by a leading academic in this field. A total of 18 interviews of between 1 and 2 hours were carried out with senior managers who either had responsibility for the company's overall KAM program or had a senior role supporting KAM.

\section{RESULTS}

The best-practice companies who participated in this research were al forecasting and planning their key customer relationships on a longer-term basis, with planning horizons ranging from two years to eleven years and detailed forecasting for between one and three years. Forecasts were revised at least annually. Several companies indicated that they were actively trying to improve their key customer forecasting, whilst one organization was developing a major software installation to help support forecasting about these customers. Forecasting was generally done on a 'bottom-up' basis, identifying different business areas within the customer and then summarizing these to arrive at a total customer forecast.

\section{Pricing and customer revenues}

The research uncovered a mismatch between what suppliers wanted to achieve with their key customers, which was value-based pricing; and that they actually achieved, which was in 
many cases based on cost-plus or competitive market rates. This suggests that customers did not see any value to themselves in value-based pricing and that they tended to be more focused on cost reduction. Some suppliers found their pricing strategies dominated by their customer's need for international price harmonization. A few were working towards a more sophisticated risk-based pricing strategy. The latter cases were the exception rather than the rule in having an approach to customers in which the view of the customer harmonized with the pricing strategy. In most cases, pricing was often relatively tactical and driven by the need to win the next contract.

All the suppliers interviewed in this research said they wanted to achieve value-based pricing with their key customers. Unfortunately, value-based pricing meant different things to the suppliers and to their key customers. To the suppliers, it meant the opportunity to charge premium prices for differentiated products and services; to customers, it often meant cost savings.

Five slightly different bases for value-based pricing were reported (Table 1).

\section{- Bring in Table 1 -}

Suppliers also reported cases where they had developed 'value-added' elements that customers didn't want and refused to pay for. This could result in a customer being thought of, wrongly, as driven mainly or entirely by price.

Cost-plus or competitive pricing 
Cost-plus or competitive pricing moves were often driven by customers. For key accounts, this was not infrequently associated with some degree of cost transparency between supplier and customer. However, suppliers reported that they were getting smarter. As one said, customers always driving for lower prices were now excluded from their global account program, "If you are always being driven to lowest price, it shows there is no loyalty" (Woodburn, Holt and McDonald, 2004 p. 124).

\section{Price harmonization}

Suppliers commonly reported that customers were asking for internationally or globallyharmonized prices. This caused cost difficulties for suppliers, several of whom reported agreeing a compromise with their customers in which the world was divided into, for example, three major regions. Prices were then harmonized within each region. Another problem that suppliers experienced with international price harmonization was achieving a global key account management structure with buy-in from all the different regions. Internal disputes could damage service to these very big customers.

\section{Risk-based pricing}

The fifth approach to pricing described by the suppliers was risk-based - that is, taking into account the riskiness of the customer. The financial stability of major customers was a source of concern for suppliers. Setting higher prices for new customers was relatively common; one supplier even set higher prices for customers in unstable market places. True risk sharing was rare; suppliers tried first to reduce risk through information and collaboration with the customer and second to protect themselves through contractual arrangements against risk. Only occasionally did suppliers consider residual risk and try to price accordingly. None of 
the suppliers in the sample appeared to have quantified approaches to measuring risk or to have a systematic process for calculating risk premiums.

\section{Costs to serve}

Rather than the sharp distinction between product costs and costs to serve suggested by the literature, suppliers commented that the distinction became blurred in their relationships with key accounts. This was because of collaboration on cost-reduction or profit-improvement projects (Table 1). Projects cited by suppliers included product redesign, supply chain management and back office system redesign. In addition to these collaborative projects, seven different types of initiative for reducing costs to serve key accounts were identified (Table 2).

- Bring in Table 2 -

Activity-based costing

As discussed above, suppliers incur substantial costs in serving customers, particularly key accounts, which are not reflected in product costs. Cooper and Kaplan (1991) have described the application of $\mathrm{ABC}$ to the measurement of customer profitability. The companies in the current research, despite being experienced in key account management, varied greatly in the degree to which they used $\mathrm{ABC}$, ranging from not at all, through ad-hoc manual $\mathrm{ABC}$ analysis of customers through to automated $\mathrm{ABC}$ on a customer by customer basis. 
The non-users either claimed that costs to serve were not a significant proportion of their costs, or felt that historic costs were unhelpful in relationship management. The manual users reported problems with complex, time-consuming processes, with one $\mathrm{ABC}$ program containing 47 elements that staff were supposed to fill out. This had obvious detrimental effects: "It seemed that, although the system could handle detailed, customer-specific information, staff could not." (Woodburn, Holt and McDonald, 2004 p.100). Best practice companies were using or setting up IT-facilitated customer profitability systems that could handle activity-based data. Even these, however, did not track $100 \%$ of costs to serve. Sometimes, data from small countries or regions were unusable or unavailable and in other cases some customer subsidiaries with very different names from the parent might remain unrecognized. However, the best practice companies did believe that the time and effort invested in the $\mathrm{ABC}$ system would pay off.

\section{Open book accounting}

One way in which companies may try to manage the costs to serve their customers is through open book accounting, in which suppliers give key customers greater visibility about the margins that the supplier is making on the goods and services it is providing. In theory, the supplier and the customer agree a 'reasonable' margin; this protects the supplier from excessive downwards price pressure from the customer and protects the customer from exploitation by the supplier.

The companies in this research expressed concerns about open book accounting, fearing that requests for open book from customers indicated a lack of trust and were potentially damaging to the relationship, although they also mentioned a number of positives (Table 3). 


\section{- Bring in Table 3 -}

This research revealed that open book initiatives were invariably customer-driven. Suppliers were suspicious of the motives (which were always about cost reduction) and were perhaps concerned about the quality of their cost data. However, those who had adopted greater transparency reported that the results were not as damaging as they had feared. Moreover, other customer initiatives to reduce cost were emerging; these included e-auctions and target costing initiatives.

\section{Managing a portfolio of key customers for maximum value}

The research showed that portfolio management of key customers had two elements: identifying the members of the key customer portfolio, and managing the portfolio of relationships.

Identifying key customers

Suppliers took three criteria into account when considering whether to add a customer to their key account portfolio: magnitude of potential business; that customer's propensity to buy the more sophisticated parts of the supplier's range; and the customer's approach to suppliers. Commonly, geographical range was also taken into account when selecting key customers, which were invariably trans-regional and usually global in their reach. All the best practice companies were able clearly to identify their key accounts. 
Another characteristic of key customer portfolio management was the recognition by suppliers that they had to limit the number of key customers in the portfolio. At the time of the research the number of key customers ranged from just 12 to 100. However, companies with more than 50 key accounts expressed concerns about the size of the portfolio.

\section{Key customer portfolio management}

The theory of portfolio management is that investors run a balanced portfolio in which some investments are performing less well in the short term, but this is counterbalanced by other high-performers. The advantage in key customer portfolio management should be that it should encourage investment in the relationship for the long term, even though the short-term payoffs in certain relationships might be lower.

The research found little evidence of real portfolio management at the key customer level. There was a tendency to treat each key customer as an individual case, understandable in the light of the size and importance of these customers. Some suppliers were able to invest in customers and even to take calculated losses if it felt this was necessary, but the true portfolio approach was by no means universal. One best-practice company had gone a stage further and had developed clear criteria for accepting a loss-making situation for longer than normal, where the customer was of strategic importance or was in a merger with another firm that was of strategic importance.

Where key customers were managed as a portfolio, this was almost invariably because there was a separate key account management operation within the business. Where a separate team or unit did not exist, it was more likely that key accounts would be managed independently rather than as a portfolio, either within countries or within product-based business units. Sometimes, deals struck globally with key customers were circumvented locally because 
profitability responsibility rested with local countries or product groups. Key account managers in these situations reported having to negotiate with individual countries, although one best-practice company had introduced a model setting out international service standards.

A combination of careful portfolio management and effective pricing delivered a substantial business success to one company. Portfolio management implies the exit as well as the entry of key customers if they no longer meet the criteria for portfolio membership. One company reported that it had implemented changes to pricing strategy that had resulted in the loss of several large but loss-making customers. The resulting improvement in business performance lifted the company from number eight to number two in its industry within a relatively short space of time.

\section{The risk of the customer}

Where companies talked about customer risk, this seemed to include two elements (Table 4):

\section{- Bring in Table 4 -}

\section{Probability of customer forecast}

Some best-practice companies adjusted customer forecasts in some way to reflect the perceived risk that the forecast might be achieved. Some multiplied the forecast by a percentage probability; others applied a 'probability hurdle' of some percentage likelihood and then only admitted business expectations to the customer forecast if they were higher than this. One company, for example, listed each customer opportunity with its probability forecast 
in the plan, but only included opportunities with probabilities greater than $80 \%$ in its customer forecast.

Risk of the customer

All the companies in this research took some account of the risk of the customer, even though several described their efforts in this direction as 'rudimentary'. The most common form of risk evaluation was financial risk, which invariably took place when the customer was acquired. Some companies continued to monitor the ability of their customers to pay, either through observation of actual payment behavior or by monitoring industry catastrophes or mergers and takeover activity. Companies in the financial sector tended to take a more expanded view and included the nature of the client, deviation from industry norms, and other factors such as geographical and product elements of risk.

Several of the best practice companies did go further in their consideration of the risk of the customer and considered risk issues such as misunderstandings of requirements, project overruns, changing customer demands etc. Sometimes such risks were discussed openly with customers and strategies to reduce risk and/or to price for it were shared. One company had adopted a very successful strategy of evaluating certain risks of the customer and then taking these risks on themselves - at a price.

\section{Barriers to risk measurement}

All the companies were concerned about the measurement of customer risk, although there were two barriers to implementation apart from lack of understanding about how to quantify customer risk. The first was key account manager motivation and the second was feedback. 
Some companies still had systems in which the key account manager was paid by short-term results. If a risk-based system was introduced and this resulted in higher prices, the key account manager might find it difficult to meet short-term targets. Therefore, remuneration schemes might have to be adjusted. In other cases, the companies failed to compare risk forecasts with actual outturns. This meant that they sacrificed potentially valuable organizational learning, as well as making the risk evaluation exercise seem unnecessary.

\section{CONCLUSIONS AND MANAGERIAL IMPLICATIONS}

This research has focused on the lessons that can be learned from the ways in which best practice companies manage the profitability of their customers. Two broad lessons emerge, one to do with the accurate measurement of the value of the customer and the other to do with the ways in which the relationships were managed.

Not surprisingly, best practice in key customer management begins with effective measurement of the value of the customer to the company. The best companies were forecasting the lifetime value of their customers and were investing in systems to help them accurately ascribe costs to customers, sometimes using activity-based costing. Moreover, best practice companies forecast customer revenues based on real customer understanding rather than superimposed targets or generalized models, and they did this on a longer-term time frame of up to three years. When pushed to adopt open book accounting, best practice companies have sound data to support their case and they accept open book accounting in appropriate circumstances and work with it positively. Exceptional companies also consider, monitor and manage customer risk.

More importantly, the research reveals best practice in key customer management. Best practice companies used a range of pricing strategies and generally aimed to implement 
value-based pricing, even though they were not always able to do so. Because they were able to take a longer-term view of their relationships with key customers, they were prepared to invest in the relationship and to adopt pricing strategies such as confirmed price reductions, shared cost savings, and shared profits. Thus, when choosing a pricing strategy, they included their view of the customer rather than pricing purely from a product or project focus. They were also able to offer some degree of price harmonization to customers. The really excellent companies incorporated their views of customer risk into their pricing and negotiated on these with the customer, even offering to transfer that risk to themselves. In this way they found a new source of customer value for which the customer was prepared to pay.

Best practice suppliers had also developed a range of initiatives to reduce the costs of serving key customers, ranging from the relatively mundane (staff reduction, target cost reduction) to the sophisticated (supply chain redesign, outsourcing customer service). The best companies had invested in activity-based costing and had a very accurate understanding of the costs to serve customers, and this understanding influenced their service offerings.

Key customer portfolio management characterized the best companies. Their portfolio management included a clear understanding of what constituted a key customer and a realistic appreciation that only relatively few truly special customers could be managed in this way. This also involved an understanding that sometimes former key customers can no longer be regarded as such and, in these cases, having some mechanism for exiting no-longer-key customers from the portfolio. The very best companies who practiced key customer portfolio management understood the principles of the balanced portfolio and were able to forego short- and even medium-term gains in the interests of the longer term.

The findings with respect to portfolio management were particularly interesting when the implications for organizational structure and processes are considered. It seems that the very best companies have a separate unit for key account management and they remunerate the key 
account managers based on appropriate long-term targets. In the very best companies the problems of the interface with country business units and the ownership of the customer P \& $\mathrm{L}$ are understood.

\section{Managerial implications}

The practical implications of this research are considerable, suggesting six areas that organizations should manage in order to manage their key customer relationships profitably: Pricing; costs to serve; activity-based costing; open book accounting / greater cost transparency with customers; key customer portfolio management; and forecasting and the understanding of customer risk.

The research has set out a multi-industry model of best practice in key account management. Managers could use this research to determine how close their own organization comes to best practice and to identify changes they might make to their current key account management practices and processes. The research strongly suggests that companies implementing KAM or intending to implement KAM should pay careful attention to the measurement of customer revenues and costs, not just in the current period (customer profitability) but also in the future. This indicates the need for effective forecasting mechanisms. The ramifications of the current research extend beyond marketing's usual scope, suggesting that organization structure and processes, plus performance measurement and remuneration policies, all have a role to play in enabling companies to manage their key customer relationships for maximum value. 


\section{REFERENCES}

A.T. Kearney (2003) Finding New Answers to the Pricing Question: What's it Worth to the Customer? Chicago: A.T. Kearney Report.

Berger, P. D. and Nasr, N.I. (1998) Customer lifetime value: Marketing models and applications. Journal of Interactive Marketing 12(1), 17-30 (Winter).

Blattberg, R.C., Getz, G. and Thomas, J.S. (2001) Customer Equity: Building and Managing Relationships as Valuable Assets. Boston: Harvard Business School Press.

Bolen, W.H. and Davies, R.J. (1997) Overreaching for mass retailers. McKinsey Quarterly 4, 40-53.

Bordley, R. (2003) Determining the Appropriate Depth and Breadth of a Firm's Product Portfolio. Journal of Marketing Research 40(1), 39-53.

Brealey, R. (1983) Risk and Return on Common Stocks. Cambridge, US: MIT Press. Cooper, R and Kaplan, R.C. (1991). Profit Priorities from ABC. Harvard Business Review 69(3), 130-134 (May-Jun).

Dhar, R. and Glazer, R. (2003) Hedging Customers. Harvard Business Review 81(5), 86-92 (May).

Doyle, P. (2000) Valuing Marketing's Contribution. European Management Journal 18(3), $233-245$.

Ferguson, R. (1987) A Comparison of the Mean-Variance and Long-Term Return Characteristics of 3 Investment Strategies. Financial Analysis Journal 43(4), $55-66$.

Gupta, S. and Lehmann D. R. (2003) Customers as Assets. Journal of Interactive Marketing 17(1), 9-24 (Winter). 
Hill, G. V. and Harland D.A. (1983) The Customer Profit-Centre. Journal of the Institute of Physical Distribution Management 2(2), 1-5.

Hogan, J. E., Lemon, K.N. and Rust R.T. (2002) Customer Equity Management: Charting New Directions for the Future of Marketing. Journal of Service Research 5(1), 4-12 (August).

Hope, J and Hope, T. (1997). Competing in the Third Wave. Boston: Harvard Business School Press.

Howell, R.A. and Soucy, S.R. (1990). Customer profitability: as critical as product profitability. Management Accounting 72(4), 43-47 (October).

Hunt, P. (2002) Analysing the psychology of pricing. Marketing Magazine 107(8), 27.

Johnson, M. D. and Selnes, F. (2004) Customer Portfolio Management: Toward a Dynamic Theory of Exchange Relationships. Journal of Marketing 68(2), 1-17 (April).

Kalwani, M.U. and Narayandas, N. (1995) Long-term manufacturer-supplier relationships: do they pay off for supplier firms? Journal of Marketing 59(1), 116 (January).

Larréché J.-C. and Srinivasan, V. (1982) STRATPORT: A Model for the Evaluation and Formulation of Business Portfolio Strategies. Management Science 28(9), 979-1001.

Larréché J.-C. and Srinivasan, V. (1981) STRATPORT: A Decision Support System for Strategic Planning. Journal of Marketing 45, 39-52 (Fall).

Lemon, K., Rust, R.T. and Zeithaml, V.A. (2001) What drives customer equity. Marketing Management 10 (1), 20-25 (Spring).

McTaggart, J.M., Kontes, P.W and Mankins, M.C. (1994) The Value Imperative Managing for Superior Shareholder Returns, New York: Free Press. 
Monroe, K. B. (2004) Pricing: Making Profitable Decisions, 3rd Edn, Irwin, NY: McGraw-Hill.

Mulhern, Francis J. (1999) Customer Profitability Analysis: Measurement, concentration, and research. Journal of Interactive Marketing 13(1), 25-40 (Winter).

Naumann, E. (1995) Creating Customer Value, Cincinnati: Thomson Executive,.

Niraj, R., Gupta, M. and Narasimhan. (2001) Customer Profitability in a Supply Chain. Journal of Marketing 65, 1-16 (July).

Noble P. M. and Gruca, T. S. (1999) Industrial Pricing: Theory and Practice. Marketing Science 18(3), 435-454.

Petromilli, M., Morrison, D. and Million, M. (2002) Brand architecture: building brand portfolio value. Strategy and Leadership 30(5), 22-28.

Reinartz, W.J. and Kumar, V. (2000). On the Profitability of Long-Life Customers in a Noncontractual Setting: an Empirical Investigation and Implications for Marketing. Journal of Marketing 64(4), 17-35.

Reinartz, W.J. and Kumar, V. (2002). The Mismanagement of Customer Loyalty. Harvard Business Review 80(7), 86-94 (July).

Reinartz, W. J. and Kumar, V. (2003) The Impact of Relationship Characteristics on Profitable Lifetime Duration. Journal of Marketing 67(1), 77-99 (January).

Rust, R.T., Lemon, K.N. and Zeithaml, V.A. (2001). Where should the next marketing dollar go? Marketing Management 10(3), 24-28 (Sept-Oct).

Ryals, L.J. (2002a). Are your customers worth more than money? Journal of Retailing and Service Studies 9, 241-251.

Ryals, L. J. (2002b) From product-based to relationship pricing. Management Quarterly 17, 3-8. 
Ryals, L. J. (2003a) Creating profitable customers through the magic of data mining. Journal of Targeting, Measurement and Analysis for Marketing 11(4), 343-349.

Ryals, L. J. (2003b) Making customers pay: measuring and managing customer risk and returns. Journal of Strategic Marketing 11(3), 165-175.

Shapiro, B.P., Rangan, V.K., Moriarty, R.T and Ross, E.B. (1987) Manage Customers for Profits (Not Just Sales). Harvard Business Review 63(5), 101-108 (SeptOct).

Sharpe, William F. (1981) Investments ( $2^{\text {nd }}$ ed.) New Jersey: Prentice-Hall.

Stedman, C. (2000) Value-based pricing. Computerworld 34(11), 58.

Urbany, J. E. (2001) Justifying Profitable Pricing. Journal of Product \& Brand Management 10(3), 141-159.

Van Raaij, E. M., Vernooij, M.J.A., and van Triest, S. (2003) The Implementation of customer profitability analysis: a case study. Industrial Marketing Management 32(7), 573-583.

Wilson C. (1996) Profitable Customers. London: Kogan Page.

Woodburn, D. and McDonald, M. (2001). Key Customers - World-leading key account management: identification and development of strategic relationships. Report by the Cranfield Key Account Management Best Practice Club, Cranfield, July 2001.

Woodburn, D., Holt, S. and McDonald, M. (2004). Key Customer Profitability: Making Money in Strategic Customer Partnerships. Report by the Cranfield Key Account Management Best Practice Club, Cranfield, January 2004. 
TABLE 1: Five bases for value-based pricing

\begin{tabular}{|c|c|c|c|c|}
\hline & Basis & Description & $\begin{array}{l}\text { Perceived } \\
\text { Advantages }\end{array}$ & $\begin{array}{l}\text { Perceived } \\
\text { Disadvantages }\end{array}$ \\
\hline 1. & $\begin{array}{l}\text { Traditional } \\
\text { premium fixed } \\
\text { price }\end{array}$ & $\begin{array}{l}\text { Customer accepts premium } \\
\text { pricing arguments. May } \\
\text { include adjustments e.g. for } \\
\text { fluctuations in raw materials } \\
\text { costs }\end{array}$ & $\begin{array}{l}\text { Very profitable if } \\
\text { achievable. }\end{array}$ & $\begin{array}{l}\text { Increasingly } \\
\text { difficult to sustain. } \\
\text { May be seen as } \\
\text { exploitative by } \\
\text { customer. }\end{array}$ \\
\hline 2. & $\begin{array}{l}\text { Bundled solution } \\
\text { pricing }\end{array}$ & $\begin{array}{l}\text { Standard product or service } \\
\text { offering wrapped with value- } \\
\text { added services and sold as a } \\
\text { complete solution }\end{array}$ & $\begin{array}{l}\text { Value-added } \\
\text { services often } \\
\text { high margin even } \\
\text { if underlying } \\
\text { product is not. } \\
\text { Cost opacity. }\end{array}$ & $\begin{array}{l}\text { Customers } \\
\text { increasingly exert } \\
\text { pressure to } \\
\text { unbundle. }\end{array}$ \\
\hline 3. & $\begin{array}{l}\text { Confirmed price } \\
\text { reductions }\end{array}$ & $\begin{array}{l}\text { Annual reductions in supplier } \\
\text { prices, either as a percentage } \\
\text { or as a target price. }\end{array}$ & $\begin{array}{l}\text { Very visible } \\
\text { benefits to } \\
\text { customer. }\end{array}$ & $\begin{array}{l}\text { Supplier expected to } \\
\text { make cost savings } \\
\text { themselves. }\end{array}$ \\
\hline 4. & Shared cost savings & $\begin{array}{l}\text { Supplier and customer } \\
\text { working together to reduce } \\
\text { costs. The savings were then } \\
\text { shared. }\end{array}$ & $\begin{array}{l}\text { Benefits of } \\
\text { collaboration with } \\
\text { supplier very } \\
\text { visible to } \\
\text { customer. }\end{array}$ & $\begin{array}{l}\text { Can result in one- } \\
\text { off savings but then } \\
\text { new lower cost base } \\
\text { becomes the norm; } \\
\text { progressively more } \\
\text { difficult to obtain } \\
\text { benefits. }\end{array}$ \\
\hline 5. & Shared profits & $\begin{array}{l}\text { Supplier invested in major } \\
\text { project alongside the } \\
\text { customer and shared the } \\
\text { profits. Most common for } \\
\text { larger, under-funded projects } \\
\text { and in the public sector. }\end{array}$ & $\begin{array}{l}\text { Benefits to both } \\
\text { parties can be } \\
\text { considerable. }\end{array}$ & $\begin{array}{l}\text { Longer term and } \\
\text { higher risk; also } \\
\text { requires investment } \\
\text { by both parties. }\end{array}$ \\
\hline
\end{tabular}


TABLE 2: Supplier initiatives to reduce the costs of serving key customers

Initiative $\quad$ Impact on costs to serve

Staff reduction Replacing operations people previously dedicated to a key account team with ad-hoc provision.

Target cost base Sometimes initiated by the customer. When initiated by the company, tended reduction to be company-wide and not particularly aimed at key accounts.

Incentivize cost In several suppliers the Key Account Manager's target had switched from reductions volume to customer profit. Sometimes, cost savings were shared with the customer (see Table 1).

Cost visibility One supplier had achieved rigorous tracking of costs to serve which it shared with the customer; both sides then collaborated in reducing these costs. Costs tracked and discussed included debt servicing, transaction handling and on-site servicing.

Dedicated staff Several suppliers had reorganized so as to provide dedicated staff. One supplier had calculated the resultant saving in SGA as 3\%, largely through learning curve effects and relationship building.

Supply chain Numerous supply chain initiatives aimed at cost reduction were found. redesign Outsourcing Several suppliers had outsourced parts of customer service, reducing or customer service redeploying the use of expensive sales force time. 
TABLE 3: Perceived advantages and disadvantages of open book accounting

\begin{tabular}{ll}
\hline Perceived advantages & Perceived disadvantages
\end{tabular}

Reduces business risk

Puts pressure on supplier margins

Allows risk sharing with customer

Diverts resources into administration

Develops experience and confidence in new

Diverts attention from real goals of the

projects

partnership i.e. performance requirements

Develops more openness between suppliers and

Deters partnerships and responsive relationships customers with suppliers

Encourages behavior that does not support the relationship, on both sides

Source: adapted from Woodburn, Holt and McDonald, 2004 
TABLE 4: Two definitions of customer risk

\begin{tabular}{lll}
\hline \multicolumn{2}{l}{ Risk } & Definition \\
\hline 1 & $\begin{array}{l}\text { Probability of customer } \\
\text { forecast }\end{array}$ & $\begin{array}{l}\text { Risk of achieving / not achieving forecast business or } \\
\text { revenues. }\end{array}$ \\
& Risk of the customer & $\begin{array}{l}\text { Risk of unexpected events in ongoing business that would } \\
\text { result in unforeseen costs being incurred by the supplier. }\end{array}$
\end{tabular}

Source: adapted from Woodburn, Holt and McDonald, 2004 